WORLD VIEW

\title{
How safe is the safety paradigm?
}

\author{
O A Arah, N S Klazinga
}

Qual Saf Health Care 2004;13:226-232. doi: 10.1136/qshc.2003.007070

This paper reviews safety initiatives in the health systems of the UK, Canada, Australia, and the US. Initiatives to tackle safety shortcomings involve public-private collaborations. Patient safety agencies (to institute learning, action and safety culture), adverse event reporting and, to a lesser extent, safety related performance indicators are currently used to design safer health systems. Their benefits are mixed, but there is little debate as to their possible side effects. Foreseeable adverse effects of multiple safety organisations stem from them being too many, too vague, too narrowly focused, threatened by the medical practice environment, and too optimistic. Safety related performance indicators are most developed in the US but suffer from inadequacies of administrative data, underreporting, variable indicator definitions, "extended" use, and low sensitivity of the diagnosis coding system, and arguable preventability of the prescribed conditions. A critical appraisal of the implications of these deficiencies is important to assure the safety of current health system safety initiatives and to establish evidence based safety. It is necessary to embed health system safety (as well as patient safety) in the societal culture, structures, and policies which promote effective, user centred, high performance care while allowing for healthy innovation.

See end of article for authors' affiliations

Correspondence to Dr O A Arah, Department of Social Medicine, Division of Clinical Methods and Public Health, Academic Medical Center, University of Amsterdam, P O Box 22700, Amsterdam 1100 $\mathrm{DE}$, The Netherlands; o.a.arah@amc.uva.nl

Accepted for publication 12 March 2004 large public-private collaborations, safety organizations, adverse event reporting systems, ${ }^{16}$ research into errors and adverse events, ${ }^{17}{ }^{18}$ and calls for system redesign. ${ }^{51920}$ Also, patient safety has become a core dimension of performance measurement and management frameworks.

However, these safety initiatives raise several questions. What are the key components of the efforts and what are they actually aimed at? Can other countries really adopt similar initiatives? If so, are they sufficiently safe and sound for crossnational learning? Will such initiatives solve the problems of health system safety? Although safety is the topic of a growing number of scientific papers, few articles have tried to critique the actual reactions to safety in health care.

In this paper we briefly examine the national agenda on and measurement of patient safety in four advanced health systems-namely, the UK, Canada, Australia, and the USA-and reflect on the potential shortcomings of these efforts. Although it is not our intention to give an exhaustive overview of national safety efforts in these four countries, we want to start a reflective discussion on their nature, direction, and potential shortcomings.

Our approach consisted of (1) exploring the relevant literature, documents, and websites on safety in the UK, Canada, Australia, and the USA; (2) seeking information from the revealed safety agencies to summarize their goals and current safety activities; (3) reviewing their national health system performance frameworks and indicators; and (4) where possible, searching the scientific literature for supporting evidence for safety related performance indicators seen in national indicator frameworks. We then reflected on all findings (summarized in the accompanying tables) from a systems perspective. This exploratory policy analysis entailed reviewing the key issues on the safety agenda and examining the "whats" and "whys" of these issues. The key findings are presented in two sections on (1) national patient safety agencies and reporting systems and (2) safety related performance indicators.

\section{NATIONAL PATIENT SAFETY AGENCIES AND REPORTING SYSTEMS}

Table 1 gives an overview of the national patient safety agencies found in the four countries.

\section{UK}

The British take quality and safety in the NHS quite seriously. ${ }^{8921-26}$ The Bristol case ${ }^{27} 28$ and other high profile affairs ${ }^{29-31}$ probably served to place the safety debate in the public domain. Following these events and two major safety publications, ${ }^{89}$ the government set up the 
Table 1 Overview of national patient safety agencies

\begin{tabular}{|c|c|c|c|c|}
\hline & $\mathrm{UK}^{*}$ & Canada & Australia & USA \\
\hline $\begin{array}{l}\text { Leading patient } \\
\text { safety } \\
\text { organization(s) }\end{array}$ & $\begin{array}{l}\text { National Patient Safety } \\
\text { Agency* }\end{array}$ & $\begin{array}{l}\text { Health Canada (HC); Canadian } \\
\text { Institute for Health Information } \\
\text { (CIHI) and the Canadian Institutes } \\
\text { of Health Research (CIHR); } \\
\text { National Steering Committee on } \\
\text { Patient Safety (NSCPS) }\end{array}$ & $\begin{array}{l}\text { Australian Council for Safety } \\
\text { and Quality in Health Care } \\
\text { (ACSQHC); Australian Patient } \\
\text { Safety Foundation (APSF) }\end{array}$ & $\begin{array}{l}\text { Agency for Healthcare Research } \\
\text { and Quality (AHRQ); National } \\
\text { Patient Safety Foundation } \\
\text { (NPSF); Joint Commission on } \\
\text { Accreditation of Healthcare } \\
\text { Organizations (JCAHO) }\end{array}$ \\
\hline Nature & $\begin{array}{l}\text { Special health authority set } \\
\text { up by the UK government } \\
\text { (Statutory Instrument } 2001 \\
\text { No. 1743) }\end{array}$ & $\begin{array}{l}\text { HC: Federal Ministry of Health, } \\
\text { Canada; } \\
\text { CIHI: independent, not-for-profit } \\
\text { body for quality health information; } \\
\text { CIHR: premier federal agency for } \\
\text { health research; } \\
\text { NSCPS: an organ of the Royal } \\
\text { College of Physicians and Surgeons }\end{array}$ & $\begin{array}{l}\text { ACSQHC: national council set } \\
\text { up by the Australian Federal } \\
\text { Health Ministers; APSF: } \\
\text { non-profit independent } \\
\text { organization dedicated to the } \\
\text { advancement of patient safety }\end{array}$ & $\begin{array}{l}\text { AHRQ: nationally authorized } \\
\text { agency for quality and safety } \\
\text { research; } \\
\text { NPSF: not-for-profit, multi- } \\
\text { disciplinary body; } \\
\text { JCAHO: independent, not-for- } \\
\text { profit, standards setting and } \\
\text { accrediting body in health care }\end{array}$ \\
\hline Web address & www.npsa.nhs.uk & $\begin{array}{l}\text { www.hc-sc.gc.ca } \\
\text { www.cihi.ca } \\
\text { www.cihr.cahttp://rcpsc. } \\
\text { medical.org }\end{array}$ & $\begin{array}{l}\text { www.safetyandquality.org } \\
\text { www.apsf.net.au }\end{array}$ & $\begin{array}{l}\text { www.ahrq.org } \\
\text { www.npsf.org } \\
\text { www.jcaho.org }\end{array}$ \\
\hline $\begin{array}{l}\text { Year national } \\
\text { safety program } \\
\text { started }\end{array}$ & July 2001 & $\begin{array}{l}\text { May } 2002 \text { (CIHI/CIHR hospital } \\
\text { safety study funding) }\end{array}$ & $\begin{array}{l}2000 \text { (ACSQHC); } \\
1989 \text { (APSF) }\end{array}$ & $\begin{array}{l}2000 \text { (AHRQ); } \\
1998 \text { (NPSF); } \\
1996 \S ; 2002^{* *}(\mathrm{JCAHO})\end{array}$ \\
\hline Mission & $\begin{array}{l}\text { To coordinate efforts to learn } \\
\text { from adverse events and } \\
\text { 'near misses' in the NHS; to } \\
\text { promote openness and } \\
\text { fairness, lead reporting and } \\
\text { feedback; to monitor progress; } \\
\text { to promote an open and fair } \\
\text { culture in the NHS }\end{array}$ & $\begin{array}{l}\text { HC: To coordinate national safety } \\
\text { agenda; } \\
\text { CIHI/CIHR: To examine the extent } \\
\text { of adverse events in Canadian } \\
\text { acute care hospitals and } \\
\text { availability of data for continuous } \\
\text { monitoring and reduction of events; } \\
\text { RCPS NSCPS: To develop } \\
\text { framework and plan for Canadian } \\
\text { patient safety efforts }\end{array}$ & $\begin{array}{l}\text { ACSQHC: To lead a national } \\
\text { and collaborative approach to } \\
\text { improve safety and quality of } \\
\text { patient care; to develop a } \\
\text { national framework, put the } \\
\text { consumer first and promote } \\
\text { research; } \\
\text { APSF: To eliminate } \\
\text { preventable harm in health } \\
\text { care }\end{array}$ & $\begin{array}{l}\text { AHRQ: To support research } \\
\text { designed to improve the } \\
\text { outcomes and quality of health } \\
\text { care, reduce its costs, address } \\
\text { patient safety and medical } \\
\text { errors; } \\
\text { NPSF: To improve patient safety } \\
\text { knowledge and awareness } \\
\text { JCAHO: To ensure a greater } \\
\text { focus on priority safe practices }\end{array}$ \\
\hline $\begin{array}{l}\text { Operational } \\
\text { mechanism }\end{array}$ & $\begin{array}{l}\text { Establishing and operating a } \\
\text { new, mandatory national } \\
\text { reporting system for adverse } \\
\text { events and "'near misses"; } \\
\text { provision of national } \\
\text { leadership and guidance }\end{array}$ & $\begin{array}{l}\mathrm{CIHI} / \mathrm{CIHR} \text { : Reviewing randomly } \\
\text { selected patient hospital records } \\
\text { by specially-trained physicians } \\
\text { and nurses who belong to the } \\
\text { research team }\end{array}$ & $\begin{array}{l}\text { ACSQHC: Using annual action } \\
\text { plans to achieve its priority } \\
\text { areas; committing to a } \\
\text { National Patient Safety } \\
\text { Research Centre, a National } \\
\text { Centre for Patient Safety } \\
\text { Improvement, system capacity } \\
\text { building, accreditation and } \\
\text { standard setting mechanisms; } \\
\text { APSF: Using its Australian } \\
\text { Incident Monitoring System }\end{array}$ & $\begin{array}{l}\text { AHRQ: Developing error- } \\
\text { reduction technologies; } \\
\text { conducting safety demonstration } \\
\text { projects and error reporting } \\
\text { strategies; supporting safety } \\
\text { research } \\
\text { NPSF: Identifying and applying } \\
\text { safety pathways; raising public } \\
\text { awareness; } \\
\text { JCAHO: Rolling safety goals for } \\
\text { accreditation; reporting and } \\
\text { analysis of sentinel events }\end{array}$ \\
\hline $\begin{array}{l}\text { Remarkable } \\
\text { public event(s) } \\
\text { on patient } \\
\text { safety }\end{array}$ & $\begin{array}{l}\text { Shipman and Ledward } \\
\text { affairs; }{ }^{29} 30 \text { high profile } \\
\text { intrathecal vincristine } \\
\text { deaths, }{ }^{31} \text { etc; Bristol case } \\
1996 \text { ( } 2001 \text { inquiry report) }{ }^{27} 28 \\
\text { An Organization with a } \\
\text { Memory, Building a Safer } \\
\text { NHS for Patients }\end{array}$ & $\begin{array}{l}\text { Lack of prior nationally } \\
\text { coordinated safety initiative; } \\
\text { error incidence unknown }{ }^{11}\end{array}$ & $\begin{array}{l}\text { Incident monitoring in } \\
\text { anesthesia }(1987 / 88) i_{i}^{43} \text { the } \\
\text { Quality in Australian Health } \\
\text { Care Study }(1995)^{38}\end{array}$ & $\begin{array}{l}\text { Harvard Medical Practice } \\
\text { studies (1991/1995); } 37 \\
\text { NPSF's Annenberg conferences } \\
(1996,1998,2001,2002){ }^{51} \\
\text { IOM's report: 'To Err is Human' } \\
(1999 / 2000)^{5}\end{array}$ \\
\hline
\end{tabular}

*Other UK safety stakeholders include National Clinical Assessment Authority, NHS Litigation Authority, Commission for Health Improvement, Coroner, Health Authority, Medical Devices Agency, Health and Safety Agency, Medicines Control Agency, and Serious Hazards of Transfusion (SHOT).

†Other initiatives are from the Canadian Council on Health Services Accreditation (CCHSA), Canadian Society of Hospital Pharmacists (CSHP), the Institute for Safe Medication Practices (ISMP Canada), Canadian Coalition on Medical Incident Reporting and Prevention (CCMIRP), Canadian Healthcare Association (CHA), Canadian Nurses Association (CNA), and provincial/territorial patient safety initiatives.

fOther national agencies in the US include the US Pharmacopoeia (USP), Food and Drug Administration (FDA), the Institute for Safe Medication Practices (ISMP), Centers for Disease Control and Prevention (CDC), Centers for Medicare and Medicaid Services (CMS), the National Forum for Health Care Quality Measurement and Reporting (NQF), the Quality Interagency Coordination Task Force (QuIC), the Leapfrog Group for Patient Safety.

$\S J C A H O$ 's sentinel event policy.

**For JCAHO's national patient safety goals.

National Patient Safety Agency (NPSA). ${ }^{25} 26$ The NPSA collates, analyzes, and feeds back information on lapses in patient safety within the NHS, and works with NHS staff and organizations to promote a fair and open culture (table 2 ). ${ }^{25}$ It also recently introduced a national reporting and learning system across the NHS to complement local level vital reporting, learning and action. Some examples of other stakeholders who are nationally or locally involved in patient safety across the UK are shown in the footnotes to table 1 .

\section{Canada}

Health Canada, the Canadian Institutes of Health Research (CIHR), and the Canadian Institute for Health Information
(CIHI) are sponsoring the investigation of the national hospital adverse events and errors to be published in late 2004..$^{101132}$ Also, Health Canada is currently funding an exploration of the possibility of a national incident reporting system. The public-private roundtable on patient safety organized by the Royal College of Physicians and Surgeons in September 2001 led to the formation of the National Steering Committee on Patient Safety (NSCPS) which has made 19 recommendations for a national integrated strategy along five themes (see table 2). ${ }^{33}$ These recommendations are similar to those made by Baker and Norton in their systematic review and report to Health Canada. ${ }^{34}$ In February 2003 the Canadian Federal Budget earmarked \$50 
Table 2 Current objectives and activities of national safety agencies in four developed countries

\begin{tabular}{|c|c|c|c|}
\hline$U^{25}$ & Canada $^{32-34}$ & Australiag $^{39-42} 13$ & USA $^{475051}$ \\
\hline National Patient Safety Agency & $\begin{array}{l}\text { Recommendations of the National Steering } \\
\text { Committee on Patient Safety }\end{array}$ & $\begin{array}{l}\text { Australian Council on Safety and } \\
\text { Quality in Health Care }\end{array}$ & $\begin{array}{l}\text { Agency for Healthcare Research and } \\
\text { Quality }\end{array}$ \\
\hline $\begin{array}{l}\text { National reporting and } \\
\text { learning system } \\
\text { (NRLS, launched 2004) } \\
\text { - Developing patient reporting } \\
\text { Root cause analysis of } \\
\text { incidents } \\
\text { - Promote open and fair } \\
\text { NHS culture for disclosure } \\
\text { and learning } \\
\text { - Active system support for } \\
\text { staff } \\
\text { - Establishing national } \\
\text { patient safety priorities } \\
\text { - Researching and developing } \\
\text { national safety solutions } \\
\text { Partnering with NHS } \\
\text { organizations to ensure } \\
\text { reporting, learning and } \\
\text { action } \\
\text { In summary, ensuring that } \\
\text { the NHS has "memory" } \\
\text { and is safer }\end{array}$ & $\begin{array}{l}\text { Establishing a Canadian Patient } \\
\text { Safety Institute (CPSI) } \\
\text { Legal and regulatory processes } \\
\text { - Measurement and evaluation } \\
\text { profinuing education and } \\
\text { - Improving information and } \\
\text { communication processes } \\
\text { Recommendations of the Baker and Norton } \\
\text { report } \\
\text { - Better national and provincial } \\
\text { reporting systems; systems } \\
\text { implementation } \\
\text { Building awareness and setting } \\
\text { priorities } \\
\text { Skills and knowledge development } \\
\text { Supporting safety efforts at } \\
\text { organizational and policy levels } \\
\text { Health Canada } \\
\text { - Providing national leadership, and } \\
\text { coordination of territorial/ } \\
\text { provincial patient safety initiatives } \\
\text { Implementing the national quality } \\
\text { and safety agenda } \\
\text { Commissioning safety research } \\
\text { Developing the Canadian } \\
\text { Medication Incident Reporting } \\
\text { and Prevention System (CMIRPS) }\end{array}$ & $\begin{array}{l}\text { Australian Patient Safety Foundation } \\
\text { Incident reporting and incident } \\
\text { monitoring aggregated from } \\
\text { system-wide health units } \\
\text { Coordinating the Australian } \\
\text { Incident Monitoring System } \\
\text { Maintaining the Generic } \\
\text { Occurrence Classification } \\
\text { for coding and reporting } \\
\text { incidents and adverse events }\end{array}$ & $\begin{array}{l}\text { Active safety research support and } \\
\text { knowledge generation on safety } \\
\text { practices and control } \\
\text { Error reporting and analysis } \\
\text { Effective technology for safety } \\
\text { Training and education of students } \\
\text { and professionals on systemic nat- } \\
\text { ure of errors } \\
\text { Development of quality indicators } \\
\text { e.g. patient safety indicators } \\
\text { Building partnerships locally, } \\
\text { nationally and internationally } \\
\text { Consumer support and education } \\
\text { National Patient Safety Foundation } \\
\text { Identifying and creating a core } \\
\text { body of knowledge } \\
\text { Identifying pathways to apply } \\
\text { the knowledge } \\
\text { Developing and enhancing the } \\
\text { culture of receptivity to patient } \\
\text { safety } \\
\text { Raising public awareness and } \\
\text { foster communications about } \\
\text { patient safety } \\
\text { - Imphieving shift in health care } \\
\text { Ioint Commission on Accreditation of } \\
\text { Healthcare Organizations } \\
\text { Supporting activities to achieve } \\
\text { core goals, (e.g. standards and } \\
\text { safe practices development, } \\
\text { consumer campaigns, patient } \\
\text { safety } \\
\text { publications, education) }\end{array}$ \\
\hline
\end{tabular}

million over 5 years for the creation of a Canadian Patient Safety Agency. The Institute for Safe Medication Practices (ISMP Canada) is an independent not-for-profit body that promotes safe medication practices, collects and analyzes medication errors, and recommends improvements. ${ }^{35}$

\section{Australia}

The Commonwealth Department of Health funded, in 1994, the Quality in Australian Health Care Study (QAHCS) to detail the degree of adverse events in Australian hospitals. Modeled on the Harvard Medical Practice Study in the US, ${ }^{36}{ }^{37}$ the QAHCS ${ }^{38}$ in June 1995 showed that $16.6 \%$ of admissions had adverse events of which $51 \%$ could be preventable. ${ }^{38}$ This publication attracted much attention, immediately resulting in the National Taskforce on Quality in Australian Health Care which recommended increased funding and establishment of a national organization for safety and quality of care. The subsequent formation in October 1996 of a National Expert Advisory Group on Safety and Quality in Australian Healthcare led to the establishment of the Australian Council for Safety and Quality in Health Care (ACSQHC) in $2000 .{ }^{12}$ It coordinates the national safety action and has so far made four reports to the Health Ministers. ${ }^{39-42}$ Other national safety efforts include the Australian Patient Safety Foundation (APSF) which developed the Australian Incident Monitoring System ${ }^{13} 3^{44}$ and a classification system for coding and reporting. ${ }^{45}$ The Australian initiatives served as the template upon which the US and UK built similar safety agencies.

\section{USA}

The Institute of Medicine's (IOM) report "To Err is Human"s is probably the most strategic publication on patient safety in the US. This report put deaths from medical error in the US at about 44 000-98 000 per annum, with 7000 of these resulting from medication errors alone. Established within 3 months of the IOM report, the Quality Interagency Coordination Task Force (QuIC) recommended some 100 actions to improve safety. ${ }^{46}$ The Agency for Health Care Research and Quality (AHRQ) oversees the federal government's interests in safety $^{47}$ (tables $\mathrm{l}$ and 2). AHRQ sponsored the Stanford University Evidenced Practice Center and the University of California to produce a critical appraisal of evidence on safety practices $^{48}$ and the AHRQ patient safety indicators (as part of the three-part AHRQ Quality Indicators project). ${ }^{49}$ The Joint Commission on Accreditation of Healthcare Organizations (JCAHO), as an independent accrediting organization, has patient safety requirements for hospitals which it accredits. ${ }^{50}$ The National Patient Safety Foundation (NPSF) aims to lead the transition from a culture of blame to that of safety. ${ }^{51}$ MedMARX is a medication error reporting program of the US Pharmacopoeia to share experiences and best quality practices. ${ }^{52}$ Other notable national or widespread initiatives are from the Institute for Safe Medication Practice ${ }^{53}$ (ISMP, a 
Table 3 Current Canadian and Australian national patient safety indicators and their properties

\begin{tabular}{|c|c|c|}
\hline & Canada $^{60}$ & Australia $^{61}$ \\
\hline $\begin{array}{l}\text { Indicator } \\
\text { topic }\end{array}$ & Hip fracture hospitalization & $\begin{array}{l}\text { Hospital separations } \\
\text { with an adverse event }\end{array}$ \\
\hline Numerator & $\begin{array}{l}\text { Age standardized acute } \\
\text { care hospitalization rate for } \\
\text { fracture of the hip per } \\
100000 \text { (ICD-9 or ICD- } \\
9-C M \text { diagnosis code of } \\
820.0-820.3,820.8 \text {, } \\
820.9 \text { ) }\end{array}$ & $\begin{array}{l}\text { Hospital separations* } \\
\text { with an adverse event } \\
\text { by an external cause } \\
\text { group (e.g. } \\
\text { misadventures, } \\
\text { complications and } \\
\text { adverse drug events }\end{array}$ \\
\hline Denominator & $\begin{array}{l}\text { Population aged } 65 \\
\text { and older }\end{array}$ & $\begin{array}{l}\text { Total annual hospital } \\
\text { separations }\end{array}$ \\
\hline $\begin{array}{l}\text { Source of } \\
\text { data }\end{array}$ & $\begin{array}{l}\text { Canadian Institute for } \\
\text { Health Information; Hospital } \\
\text { Morbidity Database }\end{array}$ & $\begin{array}{l}\text { National Hospital } \\
\text { Morbidity Database } \\
\text { (NHMD) }\end{array}$ \\
\hline $\begin{array}{l}\text { Target and } \\
\text { system level }\end{array}$ & $\begin{array}{l}\text { Safety issues in long term } \\
\text { care facilities; hospitals } \\
\text { and health system }\end{array}$ & $\begin{array}{l}\text { Safety in medication; } \\
\text { surgical and medical } \\
\text { care; hospitals }\end{array}$ \\
\hline Drawback & $\begin{array}{l}\text { May represent readmissions } \\
\text { or case transfers; may } \\
\text { overestimate incidence of } \\
\text { hip fractures; hip fractures } \\
\text { can occur independent of } \\
\text { system safety }\end{array}$ & $\begin{array}{l}\text { Data may contain } \\
\text { mislabeled cases } \\
\text { (e.g. poisonings) not } \\
\text { related to adverse } \\
\text { events }\end{array}$ \\
\hline $\begin{array}{l}\text { Latest } \\
\text { empirical } \\
\text { average }\end{array}$ & $\begin{array}{l}575 \text { per } 100000+(95 \% \\
\mathrm{Cl}: 568-582 \text { per } 100000 \\
\text { for year } 2000-2001)\end{array}$ & $264347 \ddagger$ \\
\hline
\end{tabular}

*"Separation" refers to an episode of care such as a total hospital stay (from admission to transfer, discharge, or death) or part of a hospital stay involving care change (e.g. from acute to rehabilitation).

†1999-2000.

$\ddagger$ Total number of hospital separations with adverse events in 1997-8 representing $4.8 \%$ of total separations.

not-for-profit agency that educates professionals or institutions on adverse events and runs a national Medication Errors Reporting Program with the US Pharmacopoeia), the Food and Drug Administration (with its voluntary MedWatch reporting system), ${ }^{54}$ the voluntary National Nosocomial Infection Survey of the Centers for the Disease Control and Prevention, ${ }^{55}$ and the National Quality Forum. $^{56} 57$

\section{SAFETY RELATED PERFORMANCE INDICATORS}

The development and the use of indicators within conceptual frameworks are major ways through which national governments drive performance improvement in their health systems. ${ }^{58}{ }^{59}$ The Canadian ${ }^{60}$ and Australian ${ }^{61}$ health system performance frameworks have one indicator each for patient safety-admission to hospital for hip fracture and hospital separations with an adverse event, respectively. Table 3 summarizes these two indicators. However, the ACSQHC also has sentinel events indicators which were approved by the Australian Health Ministers and which represent binomial catastrophic events of system failure deemed suitable for national aggregation. The US (AHRQ) probably has the most comprehensive set of indicators on patient safety. ${ }^{49}$ The AHRQ patient safety indicators (PSIs) represent a major undertaking to screen, at provider or system level, patient safety issues using hospital administrative data. These indicators-with empirical averages ranging from four transfusion reactions per million discharges at risk to 244.08 obstetric traumas in 1000 vaginal deliveries with instrumentation-cover surgical, obstetric and medical conditions, risk adjusted for age, sex, diagnosis related group, and comorbidity categories ${ }^{49}$ (see table 4 for an overview). The Canadian Institute for Health Information has also adopted the AHRQ safety indicators. Other indicator systems in the USA include the JCAHO Indicator Measurement System for infection control and the JCAHO sentinel events.
Table 4 Patient safety indicators of the US Agency for Healthcare Research and Quality ${ }^{49}$

\begin{tabular}{|c|c|c|}
\hline Indicator topic & $\begin{array}{l}\text { Empirical } \\
\text { average* }^{*}\end{array}$ & Drawback \\
\hline $\begin{array}{l}\text { Complications of } \\
\text { anesthesia }\end{array}$ & 0.55 & $\begin{array}{l}\text { Definition varies; underreporting; } \\
\text { unspecific denominator; unknown } \\
\text { validity }\end{array}$ \\
\hline $\begin{array}{l}\text { Death in low } \\
\text { mortality DRGs }\end{array}$ & 0.66 & $\begin{array}{l}\text { Mixed severity; no published } \\
\text { evidence of "explicit process" and } \\
\text { "staffing" construct validity }\end{array}$ \\
\hline Decubitus ulcer & 21.5 & $\begin{array}{l}\text { Mixed severity; case mix bias; } \\
\text { underreporting; conflicting validity } \\
\text { evidence }\end{array}$ \\
\hline Failure to rescue & 174.24 & $\begin{array}{l}\text { May be unpreventable; mixed } \\
\text { severity; perverse influence }\end{array}$ \\
\hline $\begin{array}{l}\text { Foreign body left } \\
\text { during procedure }\end{array}$ & 0.09 & $\begin{array}{l}\text { Non-specific denominator; rare; } \\
\text { needs stratification }\end{array}$ \\
\hline $\begin{array}{l}\text { latrogenic } \\
\text { pneumothorax }\end{array}$ & 0.67 & $\begin{array}{l}\text { Non-specific denominator; unknown } \\
\text { validity }\end{array}$ \\
\hline $\begin{array}{l}\text { Selected infections } \\
\text { due to medical care }\end{array}$ & 1.99 & Perverse influence; underreporting \\
\hline $\begin{array}{l}\text { Postoperative } \\
\text { hemorrhage or } \\
\text { hematoma }\end{array}$ & 2.06 & $\begin{array}{l}\text { Case mix bias; non-specific } \\
\text { denominator; needs stratification }\end{array}$ \\
\hline $\begin{array}{l}\text { Postoperative hip } \\
\text { fracture }\end{array}$ & 0.80 & $\begin{array}{l}\text { Case mix bias; non-specific } \\
\text { denominator }\end{array}$ \\
\hline $\begin{array}{l}\text { Postoperative } \\
\text { physiological and } \\
\text { metabolic } \\
\text { derangement }\end{array}$ & 0.89 & $\begin{array}{l}\text { Definition may vary; no published } \\
\text { construct validity evidence }\end{array}$ \\
\hline $\begin{array}{l}\text { Postoperative } \\
\text { pulmonary embolism } \\
\text { or deep venous } \\
\text { thrombosis }\end{array}$ & 9.19 & $\begin{array}{l}\text { Needs stratification; may be } \\
\text { underreported }\end{array}$ \\
\hline $\begin{array}{l}\text { Postoperative } \\
\text { respiratory failure }\end{array}$ & 3.59 & $\begin{array}{l}\text { Case mix bias; event may be } \\
\text { unavoidable }\end{array}$ \\
\hline Postoperative sepsis & 10.91 & $\begin{array}{l}\text { Definition may vary; perverse effects; } \\
\text { unclear construct validity }\end{array}$ \\
\hline $\begin{array}{l}\text { Postoperative wound } \\
\text { dehiscence }\end{array}$ & 1.93 & $\begin{array}{l}\text { Case mix bias; unclear construct } \\
\text { validity evidence }\end{array}$ \\
\hline $\begin{array}{l}\text { Accidental puncture } \\
\text { or laceration }\end{array}$ & 3.29 & $\begin{array}{l}\text { Underreporting; may be } \\
\text { unpreventable }\end{array}$ \\
\hline Transfusion reaction & 0.004 & $\begin{array}{l}\text { Rare; needs stratification; unknown } \\
\text { validity }\end{array}$ \\
\hline $\begin{array}{l}\text { Birth trauma (injury } \\
\text { to neonate) }\end{array}$ & 6.67 & $\begin{array}{l}\text { Definition may vary; mixed severity; } \\
\text { unclear construct validity }\end{array}$ \\
\hline $\begin{array}{l}\text { Obstetric trauma } \\
\text { (Cesarean delivery) }\end{array}$ & 5.93 & $\begin{array}{l}\text { Case mix bias; may be } \\
\text { unpreventable; unclear construct } \\
\text { validity }\end{array}$ \\
\hline $\begin{array}{l}\text { Obstetric trauma } \\
\text { (vaginal delivery } \\
\text { with instrument) }\end{array}$ & 244.08 & $\begin{array}{l}\text { Case mix bias; may be } \\
\text { unpreventable; unclear construct } \\
\text { validity }\end{array}$ \\
\hline $\begin{array}{l}\text { Obstetric trauma } \\
\text { (vaginal delivery } \\
\text { without instrument ) }\end{array}$ & 86.60 & $\begin{array}{l}\text { Case mix bias; may be } \\
\text { unpreventable; unclear construct } \\
\text { validity }\end{array}$ \\
\hline
\end{tabular}

*Per 1000 population at risk; represents the average performance for a nationwide sample of hospitals. Obtained from AHRQ analysis using the 2000 Healthcare Cost and Utilization Project (HCUP) State Inpatient Database (SID) for 29 states. Risk adjusted for age, sex, diagnosis related group (DRG), and comorbidity categories.

\section{DISCUSSION}

This paper has explored briefly the national safety initiatives in four advanced health systems. The use of patient safety agencies, incident reporting and learning systems, and indicators to address patient safety concerns is emerging. There are far more initiatives in use than can be highlighted in this paper, but this review gives a snapshot of the national level safety agenda. The benefits of such programmatic efforts are assumed, so we will not discuss them here. The focus here is on their disadvantages. In rushing to do something about errors in medicine, countries must concurrently critique what they are doing-given the wide range of ideas and tools being deployed-and the potential for these to become part of accountability mechanisms. Surely societies cannot afford to wait for evidence of failure of these efforts before addressing them. We first discuss the 
safety agencies and reporting systems together, and then the safety indicators.

It is important to note that the different institutional approaches to safety are related to the differences in the structure and control of the various health systems. For instance, the pluralistic US health system is, as would be expected, characterized by more safety bodies than is the case in a more uniform system such as the UK NHS (see table 1).

Safety agencies and adverse event reporting systems Foreseeable disadvantages of existing safety agencies and adverse event reporting systems seem to stem from them being too many, too vague, too narrowly focused, threatened by the medical practice environment, and too optimistic.

\section{Too many}

The safety organizations and reporting systems appear too many and may impose confusion and excessive regulatory burden on health actors. This overcrowding of the "performance environment ${ }^{\prime \prime 58}$ has been discussed in the case of NHS regulation. ${ }^{62}$ Ineffective extraneous regulation and bureaucracy slow innovation. Professionals may become risk averse, innovate less, and potentially decrease overall clinical effectiveness (because when patients are not treated, they avoid harm but they also lose out in gaining any benefits). The practice of medicine, as we know it, is an art and can be a risky venture for all involved. No two patients are identicalnor are any two errors. Even in this era of clinical guidelines, medical intricacies imply that professional providers will be innovative. Innovation is the backbone of learning and growth, offering relative advantage over the status quo. ${ }^{63}$

\section{Too vague}

There are many definitions ${ }^{51}$ and concepts of patient safety which risk making the core notions vague. The specifications, nature, and usefulness of tools used for reporting and learning from incidents are largely dependent on these still poorly aligned terminology and subjective conceptualizations. This makes room for unfortunate mix ups and wrong analysis. There are debates on whether safety should focus on medical injuries ${ }^{64}$ or errors. ${ }^{65}$ Furthermore, safety and effectiveness as dimensions of performance appear to overlap when we include errors of omission within safety. For emphasis and action, errors of omission deserve to be separated out as safety issues, especially since not doing the right thing is not only ineffective, but also harmful when the wrong thing is done instead.

\section{Too narrowly focused}

Although this paper examines patient safety initiatives, it is evident that current efforts focus too narrowly on the patient with little explicit linkage to wider aspects of health system safety. Risk management entails reducing harm not just to patients but also to staff, visitors, ${ }^{3}$ and the environment (including the society). Many national safety initiatives try to address all these, albeit disjointedly. Furthermore, as shown in tables 3 and 4, staff and environmental safety measures are not currently captured in performance frameworks. Obviously, health systems cannot treat these other aspects as independent concerns.

\section{Threatened by the medical practice environment} The medical practice environment remains prohibitively litigious. The current safety paradigm does not seem to be winning against the tort system and apportioning of blame. Espousing a no-fault rationale in the public domain, while the blame culture rages, has done little to stem the litigation tide. Nor has the current approach to "safety culture" (restricted to the health and legal systems) helped. As in the wider quality movement, voluntary disclosure and partial openness further undermine these efforts. ${ }^{66-68}$

\section{Too optimistic}

Current thinking on patient safety reflects a zero tolerance of harm. With abundant referencing to the aviation and other industries, and from quality management cycles to cognitive meta-systems, ${ }^{69}$ research has enabled health systems to adopt systems engineering and causal analytical rationales and tools from the non-medical world. Where these allied and industrial sectors have established safety nets, expected minimums, and unavoidable maximums, medicine has no acceptable levels of adverse events and errors, nor should it. A practical approach so far has been to fight the frequency and severity of adverse events to the barest levels possible. An obvious disadvantage is that we become too hopeful in the short to medium term but disenchanted in the long term when we get mixed results. In the absence of exhaustive data on the lapses and of evidence of what works and what does not, our zero tolerance may remain naively optimistic.

\section{Safety indicators}

Even at a national headline level, just reporting on hip fracture as seen in the Canadian health indicators framework will not give a balanced view of health care safety (table 3 ). The US AHRQ safety indicators are more extensive but suffer from the shortcomings related to administrative data, underreporting, indicator definitions, and preventability of the prescribed conditions (see table 4 ). ${ }^{70}$ Their use of hospital administrative data imports the problems of incomplete data and inaccurate and variable coding of ICD-9-CM (International Classification of Diseases, $9^{\text {th }}$ edition, Clinical Modification) diagnosis fields. ${ }^{71}$ Also, the ICD-9-CM coding system was not created with safety issues in mind and is therefore inadequate for identifying errors and injuries. ${ }^{72}$ Basing safety tools on administrative data increases the likelihood of low sensitivity of these indicators in flagging incidents. ${ }^{73}$ Although much has been done to increase the validity and reliability of the AHRQ performance safety indicators, there is still a long way to go. Combining anesthetic complications together into one measure is clearly counterproductive as the total count may stabilize while the constituent conditions vary tremendously. In addition, the AHRQ performance safety indicators specify medical conditions less than they do surgical problems. Consequently, these safety indicators will be more problematic than other quality measures among end users. Given the litigious medical practice environment, such ambiguities are unhelpful, if not unsafe.

\section{What can be done?}

Countries can and should strive towards evidence based safety. The issues raised above will need to be addressed to create re-prioritized, coherent, deeper, more focused, and realistic safety initiatives with an encouraging medicolegal environment. This re-prioritization should learn from established approaches used in evidence based medicine and rational decision making. Safety policies should invest more in safety issues with the largest impact and conduct a better search for more rigorous evidence of effectiveness.

By investing more, both financially and otherwise, countries must critically:

- avoid useless and potentially harmful duplication of initiatives or systems;

- clarify and unify concepts and definitions;

- expand and integrate the scope of safety within and beyond the health system; 


\section{Key messages}

- Health system safety has recently become an urgent issue in many industrialized nations, notably, UK, Canada, Australia and USA.

- These countries have all engaged in safety initiatives such as patient safety agencies, adverse event reporting and learning systems, and the use of safety performance indicators.

- The benefits of such programmatic efforts are assumed, but it is still unclear how effective these multiple initiatives are. Furthermore, little attention has been paid to their potential side effects.

- These shortcomings which can exacerbate the initial safety and health problems should be anticipated and guarded against from the outset, especially as these initiatives can become accountability tools.

- Both effects and side effects of current initiatives need careful rigorous evaluation to achieve evidence based safety in health systems.

- address the policies and societal environment which hinder the inception of a culture of safety, fairness. and openness with the wider society;

- redesign the training and working conditions of providers;

- engage patients and their families as partners in health; and

- search for better data sets and coding system for safety indicators as well as re-evaluate the preventability of measured conditions.

\section{CONCLUSIONS}

Ensuring safety of health systems has led to the creation of agencies, networks, and policies that may well become new bureaucracies and regulatory mechanisms, and may discourage learning and growth when they overburden professionals with new jargons, new protocols, and new responsibilities. Providers, who must work with patients as partners, are the key to any system redesign to confront patient safety. ${ }^{20} 74$ "II]gnoring the occasional need for innovation can lead to robot-like execution of procedures in an unthinking, unreflecting manner which is surely not in the best interest of the patient." 75

Furthermore, as other countries adopt these patient safety models which become part of national accountability and performance frameworks, it is imperative to explore their transferability and to find out how such efforts actually affect the safety culture, structures, practices, and outcomes. Contextual analysis is indispensable for successful application, acceptance, and appraisal of safety tools. ${ }^{76}$ It is not enough to investigate whether these systems work; it is imperative to find out how and why they reduce errors and adverse events. ${ }^{19} 77$

We argue that, when it comes to routine surveillance or performance measurement using indicators or both, performers become what they measure or are expected to deliver. How effective these initiatives become depends on how well they are embedded in the medical culture, structures, and policies which promote effective patient centred care. As avoiding harm has been a fundamental tenet of medicine since Hippocrates, we should remember to balance the "doing no harm" (safety) with "doing good" (effectiveness or quality health care) at the level of both the individual patient and the health system.

\section{ACKNOWLEDGEMENTS}

The views in this article are entirely those of the authors. No official endorsements by the various institutions or affiliated persons are intended or should be inferred. The authors are grateful to the following for information on their respective organizations or countries: Lucy Bolton (National Patient Safety Agency, UK), Pierrete Leonard (Royal College of Physicians and Surgeons of Canada), Helen McElroy and Michekke Budak (Health Canada), Mark Bisby (Canadian Institutes for Health Research), Barbara Levings (Australian Council for Safety and Quality in Health Care), Deborah Queenan (Agency for Healthcare Research and Quality, USA), and Richard J. Croteau (Joint Commisison on Accreditation of Healthcare Organizations, USA).

\section{Authors' affiliations}

O A Arah, Netherlands Institute for Health Sciences, Erasmus MC, University Medical Center Rotterdam, Rotterdam, The Netherlands O A Arah, N S Klazinga, Department of Social Medicine, Division of Clinical Methods and Public Health, Academic Medical Center, University of Amsterdam, Amsterdam, The Netherlands

Funding: Ministry of Health, Welfare and Sport, The Hague, the Netherlands.

\section{REFERENCES}

1 McGlynn EA, Brook RH. Keeping quality on the policy agenda. Health Aff $2001 ; 20: 82-90$.

2 Joint Commission on Accreditation of Healthcare Organizations. What every hospital should know about sentinel events. Oakbrook Terrace, CA: Joint Commission on Accreditation of Healthcare Organizations, 2000.

3 Joint Commission on Accreditation of Healthcare Organizations. Glossary of terms. Oakbrook Terrace, CA: Joint Commission on Accreditation of Healthcare Organizations, 2001.

4 Leape LL, Lawthers AG, Brennan TA, et al. Preventing medical injury. QRB Qual Rev Bull 1993; 19:144-9.

5 Kohn LT, Corrigan JM, Donaldson MS, eds. To err is human: building a safer health system. Washington, DC: National Academy Press, 2000

6 Andersen B, Fagerhaug T. Root cause analysis: simplified tools and techniques. Milwaukee, WI: American Society for Quality, 1999.

7 Vincent CA, Coulter A. Patient safety: what about the patient? Qual Saf Health Care 2002;11:76-80.

8 Department of Health. An organisation with a memory. Report of an expert group on learning from adverse events in the NHS. London: The Stationery Office, 2000.

9 Department of Health. Building a safer NHS for patients. Implementing an organisation with a memory. London: Department of Health, 2001.

10 Canadian Institute for Health Information. Adverse events in Canadian hospitals. http://secure.cihi.ca/cihiweb/dispPage.jsp?cw_page = adevents_e (accessed 4 March 2003).

11 Canadian Institutes of Health Research. Study to examine adverse events in Canadian hospitals. http://www.cihr-irsc.gc.ca/e/news/8021.shtml (accessed 4 March 2003).

12 Australian Council for Safety and Quality in Health Care. http:// www.safetyandquality.org (accessed 13 March 2003).

13 Australian Patient Safety Foundation. http://www.apsf.net.au/ (accessed 9 October 2003).

14 Raef S. Denmark launches patient safety initiative. Focus on Patient Safety 2002;5:1-2.

15 Danish Society for Patient Safety. Patient safety: the Danish experience. http://www.pgeu.org/webdata/docs/Symp\%202003\%20Lilja.ppt (accessed 11 October 2003).

16 Leape LL. Reporting of adverse events. N Engl J Med 2002;347:1633-8.

17 Wolff AM, Bourke J. Reducing medical errors: a practical guide. Med J Aust 2000;173:247-51.

18 Wolff AM, Bourke J, Campbell IA, et al. Detecting and reducing hospital adverse events: outcomes of the Wimmera clinical risk management program. Med J Aust 2001;174:621-5.

19 Locock L. Healthcare redesign: meaning, origins and application. Qual Saf Health Care 2003; 12:53-7.

20 Richardson WC, Corrigan JM. Provider responsibility and system redesign: two sides of the same coin. Health Aff 2003;22:116-8.

21 Department of Health. The new NHS-modern and dependable. London: Department of Health, 1997.

22 Department of Health. A first class service: quality in National Health Service. London: Department of Health, 1998.

23 Department of Health. A commitment to quality. A quest for excellence. London: Department of Health, 2001

24 Neale G, Woloshynowych $M$, Vincent $C$. Exploring the causes of adverse events in NHS hospital practice. J R Soc Med 2001;94:322-30.

25 National Patient Safety Agency. www.npsa.nhs.uk/ laccessed 23 January 2003).

26 Department of Health, National Patient Safety Agency. Doing less harm. London: National Patient Safety Agency, 2001 
27 The Bristol Royal Infirmary Inquiry. Learning from Bristol: the report of the public inquiry into the children's heart surgery at the Bristol Royal Infirmary 1984-1995. London: The Stationery Office, 2001.

28 GMC News. The Bristol case: a serious departure from safe professional standards. London: General Medical Council, 1998. www.gmc-uk.org/ news/archive/bristol.htm (accessed 6 February 2003).

29 Baker R. Harold Shipman's clinical practice, 1974-1998. London: The Stationery Office, 2001.

30 Abbasi K. Reviews. "Butchers and gropers." BMJ 1998;317:1599.

31 Dyer $C$. Doctors suspended after injecting wrong drug into spine. BMJ 2001;322:257

32 Health Canada. www.hc-sc.gc.ca/english/care/index.html laccessed 18 March 2003).

33 National Steering Committee on Patient Safety. Building a safer system-a national integrated strategy for improving patient safety in Canadian health care. Ottawa, ON: National Steering Committee on Patient Safety, 2002.

34 Baker GR, Norton P. Patient safety and healthcare error in the Canadian healthcare system - a systematic review and analysis of leading practices in Canada with reference to key initiatives elsewhere. Ottawa: Health Canada, 2002.

35 Institute for Safe Medication Practices, Canada. http://www.ismp canada.org (accessed 5 March 2003).

36 Brennan TA, Leape LL, Laird NM, et al. Incidence of adverse events and negligence in hospitalized patients. Results of the Harvard Medical Practice Study I. N Engl J Med 1991;324:370-6.

37 Leape LL, Brennan TA, Laird N, et al. The nature of adverse events in hospitalized patients. Results of the Harvard Medical Practice Study II. N Engl J Med 1991;324:377-84.

38 Wilson RMcL, Runciman WB, Gibberd RW, et al. The Quality in Australian Healthcare Study. Med J Aust 1995; 163:458-71

39 Australian Council for Safety and Quality in Health Care. Safety first. Report to the Australian Health Ministers' Conference, 27 July 2000. Canberra: Australian Council for Safety and Quality in Health Care, 2000.

40 Australian Council for Safety and Quality in Health Care. Second national report on patient safety: improving medication safety. Canberra: Commonwealth of Australia, 2002.

41 Australian Council for Safety and Quality in Health Care. Safety through action-Improving patient safety in Australia. Third national report to the Australian Health Ministers' Conference, 19 July 2002. Canberra: Commonwealth of Australia, 2002

42 Australian Council for Safety and Quality in Health Care. Patient safety: towards sustainable improvement. Fourth report to the Australian Health Ministers' Conference, 31 July 2003. Canberra: Commonwealth of Australia 2003.

43 Runciman WB. The Australian Patient Safety Foundation. Anaesth Intensive Care 1988;18:114-6.

44 Runciman WB. Lessons from the Australian Patient Safety Foundation: setting up a national patient safety surveillance system - is this the right model? Qual Saf Health Care 2002;11:246-51.

45 Runciman WB, Helps SC, Sexton EJ, et al. A classification for incidents and accidents in the health-care system. J Qual Clin Pract 1998;18:199-211.

46 Quality Interagency Coordination Task Force (QuIC). Doing what counts for patient safety: federal actions to reduce medical errors and their impact. Rockville, MD: Quality Interagency Coordination Task Force, 2000.

47 Agency for Healthcare Research and Quality. Medical errors and patient safety. www.ahcpr.gov/qual/errorsix.htm (accessed 27 March 2003).

48 Shojania KG, Duncan BW, McDonald KM, et al. Making health care safer: a critical analysis of patient safety practices. Evidence report/ technology assessment no 43; AHRQ publication 01-E058. Rockville, MD Agency for Healthcare Research and Quality, 2001.

49 Agency for Healthcare Research and Quality. Patient safety indicators Version 2.1. Rockville, MD: Agency for Healthcare Research and Quality, 2003.
50 Joint Commission on Accreditation of Healthcare Organizations. Patient safety, www.jcaho.org/accredited+organizations/patient+safety/index.htm (accessed 10 January 2003).

51 National Patient Safety Foundation. www.npsf.org (accessed 5 March 2003).

52 US Pharmacopeia. MedMARX: Patient safety solutions. www.usp.org/ (accessed 5 March 2003)

53 The Institute for Safe Medication Practices, United States. www.ismp.org/ accessed 5 March 2003).

54 MedWatch of Food and Drug Administration. www.accessdata.fda.gov/ scripts/medwatch/medwatch_online.cfm (accessed 5 March 2003).

55 National Nosocomial Infection Survey. www.cdc.gov/ncidod/hip/NNIS/ @nnis.htm (accessed 5 March 2003).

56 National Quality Forum. The National Forum for Health Care Quality Measurement and Reporting. www.qualityforum.org/ laccessed 27 March 2003).

57 Kizer KW. Patient safety: a call to action: a consensus statement from the National Quality Forum. MedGenMed 2001;3:10

58 Arah OA, Klazinga NS, Delnoij DMJ, et al. Conceptual frameworks for health systems performance: a quest for effectiveness, quality and improvement Int J Qual Health Care 2003;15:377-98.

59 McLoughlin V, Leatherman S, Fletcher M, et al. Improving performance using indicators: Recent experiences in the United States, the United Kingdom, and Australia. Int J Qual Health Care 2001;13:455-62.

60 Canadian Institute for Health Information. Health indicators, 2003. Ottawa: Canadian Institute for Health Information, 2003.

61 National Health Performance Committee. National report on health sector performance indicators 2001. Brisbane: Queensland Health, 2002.

62 Walshe K. The rise of regulation in the NHS. BMJ 2002:324:967-70.

63 Rogers EM. Diffusion of innovations. New York: Free Press, 1983.

64 Layde PM, Cortes LM, Teret SP, et al. Patient safety efforts should focus on medical injuries. JAMA 2002;287:1993-7 (erratum, JAMA 2002;287:2363).

65 McNutt RA, Abrams R, Arons DC. Patient Safety Committee. Patient safety efforts should focus on medical errors. JAMA 2002;287:1997-2001.

66 McCormick D, Himmelstein DU, Woolhandler S, et al. Relationship between low quality-of-care scores and $\mathrm{HMOs}^{\prime}$ subsequent public disclosure of qualityof-care scores. JAMA 2002;288:1484-90.

67 Arah OA. Public disclosure of health plan quality of care. JAMA 2003;289:846-7

68 Thompson JW, Pinidiya SD, Ryan KW, et al. Health plan quality-of-care information is undermined by voluntary reporting. Am J Prev Med 2003;24:62-70.

69 Vincente KJ. From patients to politicians: a cognitive engineering view of patient safety. Qual Saf Health Care 2002;11:302-4

70 Zhan C, Miller MR. Excess length of stay, charges, and mortality attributable to medical injuries during hospitalization. JAMA 2003;290:1868-74.

71 Hsia DC, Krushat WM, Fagan AB, et al. Accuracy of diagnostic coding for Medicare patients under prospective payment system. N Engl J Med 1988;318:352-5 (erratum, N Engl J Med 1990;322:1540).

72 Geraci JM, Ashton CM, Kuykendall DH, et al. International Classification of Diseases, 9th Revision, Clinical Modification codes in discharge abstracts are poor measures of complication occurrence in medical inpatients. Med Care 1997; 35:589-602.

73 Weingart SN, lezzoni LI, Davis RB, et al. Use of administrative data to find substandard care: validation of the complications screening program. Med Care 2000:38:796-806.

74 Millenson ML. The silence. Health Aff 2003;22:103-12

75 Sheridon TB. Human error. Qual Saf Health Care 2003; 12:383-5.

76 Arah OA. Professional monitoring and critical incident reporting using personal digital assistants. Med J Aust 2003;178:359.

77 Walshe K, Freeman T. Effectiveness of quality improvement: learning from evaluations. Qual Saf Health Care 2002;11:85-7. 